\title{
SUBACUTE TOXICITY OF DECAHEDRON AND SPHERAL SILVER NANOPARTICLES IN RATS
}

\author{
N. Andriychuk ${ }^{1}$, L. Vlasyk ${ }^{1,2}$ \\ ${ }^{1}$ Higher State Educational Establishment of Ukraine "Bukovinian State Medical University", \\ Chernivtsi, Ukraine \\ ${ }^{2}$ L.I. Medved's Research Center of Preventive Toxicology, Food and Chemical Safety, \\ Ministry of Health, Ukraine (State Enterprise), Chernivtsi, Ukraine
}

\begin{abstract}
The safety of nanomaterials and nanotechnologies is an important factor in the regulation of industrial production and the introduction of nanoproducts into practice. The toxicological aspect of the use of silver nanoparticles (SNP) is insufficiently studied, leaving many questions without answer. The problem of dependence of toxicity on the shape and the size of nanoparticles is controversial and not well-studied, and there is a lack of research on the nanosilver effect on human and animal organisms.

Objective. The aim of the work was to provide the hygienic assessment of harmful effects of silver nanoparticles of spherical and decahedron shape.

Materials and Methods. Samples of solutions of spherical and decahedron SNP, synthesized by the method of photostimulated restoration, were intraperitoneally administered to white nonlinear rats both males and females aged 4 months. For the subacute toxicity study of spherical 45-nm nanosilver the animals were subdivided into three groups of (16 rats in each, 8 animals in a subgroup - according to gender). Every day they were injected with spherical SNP at doses of $0.1,1$ and $5 \mathrm{mg} / \mathrm{kg}$ intraperitoneally for 14 days. The fourth group was the biological control. For the subacute toxicity study of decahedron 45-nm nanosilver the animals were subdivided into four groups (16 rats in each, 8 animals in the subgroup according to gender). The animals were injected intraperitoneally with 10, 5, 1, and $0.1 \mathrm{mg} / \mathrm{kg}$ doses of SNP daily for 14 days. Fifth group was biological control. On 14th day animals were withdrawn from the experiment by decapitation under a slight, ethereal athetic.

Results and Discussion. It was grounded the expediency of taking into account the physical and chemical properties of silver nanoparticles, including geometrical characteristics (shape, specific area of surface), the number of silver ions in nanoparticle and the quantity of nanoparticles in the solution while the determination of exposition of nanosilver or other nanochemicals of different geometric shapes. On models of subacute effect there were determined the peculiarities of different shapes nanosilver exposure and hygienic meaning of biochemical and pathomorphological changes as criteria of harmful effect. With the help of morphometric analysis of pathomorphological changes of internal organs of rats there was ascertained doserelated harmful effect of decahedron and spherical silver nanoparticles. As a result of the experiment, dose-dependent circulating swelling of the epithelium of convoluted tubules of the kidneys, hepatocytes, nuclei of cardiomyocytes, alteration of the epithelium of bronchi of different caliber, repletion of the blood vessels of the walls of the respiratory parts of the lungs, karyopicnosis of neurons of the cerebral cortex were observed. The revealed changes in the indices of prooxidant-antioxidant equilibrium, some biochemical indices and the changes in internal organs of animals testified to the less toxic effect of silver nanospheres in comparison with silver nanodecahedrons.

Conclusions. 1. According to the analysis of the geometric characteristics of decahedron silver nanoparticles, it is established that the specific area of decaheders is 2 times bigger than the specific area of the spherical SNP, which provides twice bigger area of the contact of silver nanodecahedron in the biological environment. The decahedron nanoparticle contains 4.3 times less atoms than spherical, and, at the same mass concentration, a solution of nanosilver contains 4 times more silver nano decahedrons than spheres.

2. With the help of biochemical analyses of blood and liver tissue, as well as the morphometric analysis of pathological changes in the internal organs of laboratory rats, the dose-dependent harmful effect of silver nanoparticles of decahedral and, partially, spherical shape was established. The revealed changes in the blood and internal organs of animals testified to a less toxic effect of silver nanospheres in comparison with silver nanodecahedrons.

3. It was established that the differences in biochemical and pathomorphological changes in the internal organs of laboratory animals at the same dose of SNP the decahedron and spherical shape, calculated in $\mathrm{mg} / \mathrm{kg}$ body weight, are related to a 4-multiple dose difference expressed in the ratio of "the number of nanoparticles $/ \mathrm{kg}$ " of body weight and a 9-multiple difference in favor of nanodecahedrons while calculating the dose "specific surface area/ $\mathrm{kg}$ " of body weight.
\end{abstract}

Key Words: silver nanoparticles, silver nanodecahedron, silver nanosphere, toxicity, nanosilver.

\section{Introduction}

The rapid development of nanotechnology requires the rapid development of approaches to hygienic assessment of nanoparticles, one of the main stages of which is to assess their toxicity. However, the issue of studying the safety of nanotechnologies and nanomaterials is still at the stage of development of norms, require- ments, methodologies and standards. With regard to general questions on the evaluation of toxicity and safety of nanoparticles, there is still a significant lack of information [4]. Scientific researches, devoted to the effect of nanoparticles on human health, animals, plants and ecological sustainability of the environment, does not cover a large number of 


\section{ОРИГІНАЛЬНІ ДОСЛУДЖЕННЯ}

\section{НАНОТОКСИКОЛОГІЯ}

used or advanced species of nanoparticles, a variety of factors of their possible effects on health [5]. And although some publications say that not all nanoparticles are harmful to living organisms, scientific literature collects information every year, indicating that they have a potential and actual danger to living organisms [7]. The safety of nanomaterials and nanotechnologies is an important factor in the regulation of industrial production and the introduction of nanoproducts into practice.

Recent years studies have been connected with the dependence of nanoparticles toxicity on the form, size, source material, surface area, charge, dose, route of admission, concentration in the target organ, solubility and duration of action $[1,3]$.

The toxicological aspect of the use of silver is insufficiently studied, leaving many questions without answer. The problem of dependence of toxicity on the shape and the size of nanoparticles is controversial and not wellstudied, and there is a lack of research on the nanoparticles effect on human and animal organisms [11]. That is why these issues are the key issues in the context of the safety of newly created nanosilver products.

The literature describes studies on acute, subacute, and subchronic toxicity of spherical nanosilver of various sizes introduced to rats, mice or guinea pigs, intragastrically, intravenously, transdermally and inhalation $[8,12,13]$. The dimensionally dependent [11,12], dosedependent [9,10] and sex-dependent [11] cumulations of silver nanoparticles (SNP) in tissues of the internal organs of rats and mice $[14,15,16]$ were revealed. These works relate to the determination of toxicity of various sizes spherical SNP. At the same time, not all researchers indicate in their work the shape of the studied SNP, focusing on the size or dose of SNP. Although taking into account the shape of the nanoparticles plays an important role in the toxicity study.

Most of experimental researches use the nanoparticle mass index for the unit of measurement of the dose of SNP, without paying due attention to such characteristics as the number of particles, the specific surface area.

Due to its special physicochemical properties, unique optical properties (intense narrow band of plasmonic scattering and absorption), good reproducibility of synthesis, high stability of solutions of decahedron SNP are perspec- tive materials for the creation of optical biosensors and biomixes on their basis. Literary data still have lack information on the hygienic assessment of silver nanodecaheders, which are actively used in optoelectronics, biological labels, solar cells, various scientific studies and other industries [6].

Aim of the Research. The aim of the work was to realize the hygienic assessment of harmful effects of silver nanoparticles of spherical and decahedron shape.

Methods and Materials. We used samples of solutions of spherical and decahedron SNP synthesized by the method of photostimulated restoration. Explored objects were made by the staff of the Department of Inorganic Chemistry of Chernivtsi National University named after Y. Fedkovich.

Nanosilver was obtained by chemical regeneration of $\mathrm{Ag}+$ ions with sodium borohydride in the presence of sodium citrate and polyvinylpyrrolidone, followed by photochemical effects of a $470 \mathrm{~nm}$ wavelength LED light. Investigation of translucent electron microscopy showed that the obtained nanomaterials have a structure of flat decahedrons with a $45 \mathrm{~nm}$ diameter and a height of 30-40 $\mathrm{nm}$. Polyvinylpyrrolidone was used as a stabilizer.

The subacute toxicity study of SNP was performed on white nonlinear rats both males and females aged 4 months. The animals were kept under stable vivarium conditions (air temperature $-+18^{\circ} \ldots+20^{\circ} \mathrm{C}$, relative humidity 30 $60 \%$ ). Animals received standard granulated feed for laboratory rats (manufactured by ATCC "Phoenix", Ukraine) and water for drinking water without any restrictions. The content of nitrates and pesticides in feed and water did not exceed their MPC. All researches on animals [76] were conducted in accordance with BSS 42 1-88 "Laboratory animals. Technological process", in compliance with the basic provisions of the Council of Europe Convention on the Protection of Vertebrate Animals Used in Experiments and Other Scientific Purposes of 18.03.1986, the EU Directive No. 609 of 24.11.1986 and the Law of Ukraine No. 692 of January 21, 2006 p.

For the subacute toxicity study of spherical 45-nm nanosilver the animals were subdivided into three groups of (16 rats in each, 8 animals in a subgroup - according to gender). Every day they were injected with spherical SNP at 


\section{ОРИГІНАЛЬНІ ДОСЛІДЖЕННЯ}

\section{НАНОТОКСИКОЛОГІЯ}

doses of $0.1,1$ and $5 \mathrm{mg} / \mathrm{kg}$ intraperitoneally for 14 days. The fourth group was the biological control.

For the subacute toxicity study of decahedron 45-nm nanosilver the animals were subdivided into four groups (16 rats in each, 8 animals in the subgroup according to gender). The animals were injected intraperitoneally with $10,5,1$, and $0.1 \mathrm{mg} / \mathrm{kg}$ doses of SNP daily for 14 days. Fifth group was biological control. On $14^{\text {th }}$ day animals were withdrawn from the experiment by decapitation under a slight, ethereal athetic.

The statistical processing of the results obtained during the implementation of the work was performed in the program package "Microsoft Excel" and "STATISTICA 6.0" using parametric methods for evaluating the obtained data. The reliability of the difference between independent quantitative values was determined by the $\mathrm{t}$-criterion of the Inves-tigator. Changes were statistically significant at $\mathrm{P}<0.05$.

\section{Results and Discussion}

The calculations show that the decahedron nanoparticle contains 4.3 times less atoms than the spherical one. Consequently, it can be affirmed that, if the decahedron SNP contains 4 times less silver atoms than the spherical one, so at a same mass concentration of a solution of nanosilver, this solution contains 4 times more nanosilver decahedrons than spheres. Thus, the question, concerning the obligatory consideration of not only the mass but also the quantitative concentration of the SNP in the solution, and, therefore, the doses of nanoparticles in these units, arises.

The next stage of the research was the study of subacute effect of the decahedron SNP solution. Dose-dependent statistically significant changes in the parameters of prooxidantantioxidant balance were revealed. As a result of the introduction of a solution of silver nanodecahedrons, an increase of the level of malonic aldehyde (MA) in the blood was detected by $37 \%(p<0,05)$ and by $56 \%(p<0,05)$ at doses of 5 and $10 \mathrm{mg} / \mathrm{kg}$, respectively, in rat liver tissue at $18(\mathrm{p}<0.05)$ and $25 \%(\mathrm{p}<0.05)$, respectively, for the introduction of the two largest doses of the SNP solution (fig. 1). The catalase activity (CA) of the blood increased by $10 \%(\mathrm{p}<0,05)$ at $5 \mathrm{mg} / \mathrm{kg}$ dose and by $17 \%$ $(p<0,05)$ at the maximum dose administered. Liver CA decreased by $26 \%$ at doses of $1 \mathrm{mg} / \mathrm{kg}$ and by $36-37 \%(\mathrm{p}<0,05)$ at 5 and $10 \mathrm{mg} / \mathrm{kg}$ doses (fig. 2). Glutathione peroxidant (GP) blood activity decreased by $27 \%(\mathrm{p}<0,05)$ at the dose of SNP of $5 \mathrm{mg} / \mathrm{kg}$ and by $58 \%(\mathrm{p}<0,05)$ for the administration of a maximum dose of $10 \mathrm{mg}$ $/ \mathrm{kg}$. The GP of the liver significantly increased by $22-23 \%(p<0,05)$ at the dose of SNP 1 and $5 \mathrm{mg} / \mathrm{kg}$ and by almost $34 \%(\mathrm{p}<0,05)$ at the dose of SNP $10 \mathrm{mg} / \mathrm{kg}$. The activity of alkaline phosphatase was almost twice as high as the dose of $5 \mathrm{mg} / \mathrm{kg}$ and in $2.7(\mathrm{p}<0.05)$ times at $10 \mathrm{mg} / \mathrm{kg}$ dose. The level of cholesterol increased by $2.5(p<0.05)$ and $3(p<0.05)$ times, respectively, with the increase of the dose of decahedron SNP.

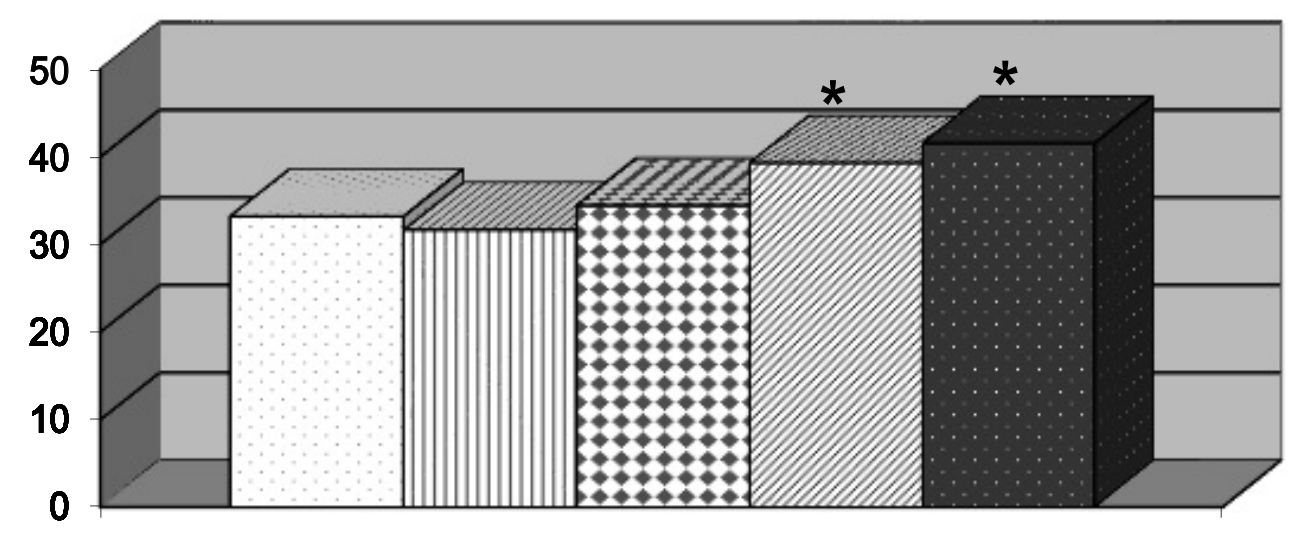

口control $\square 0,1 \mathrm{mg} / \mathrm{kg} \quad \square 1 \mathrm{mg} / \mathrm{kg} \square 5 \mathrm{mg} / \mathrm{kg} \square 10 \mathrm{mg} / \mathrm{kg}$

Fig. 1. The content of malonic aldehyde $(\mu \mathrm{mol} / \mathrm{g})$ in rat liver tissue under conditions of subacute effect of different doses of decahedron SNP Note: ${ }^{*}$ - $\mathrm{p}<0,05$ relative to control 


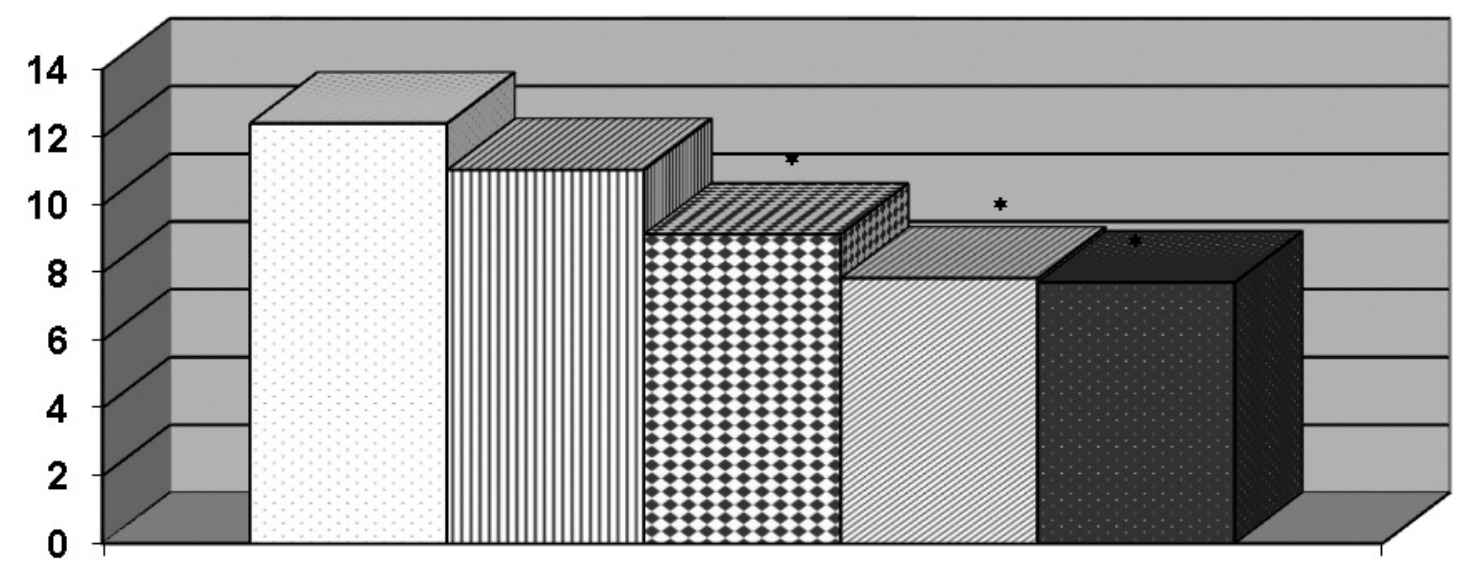

$\square$ control $\square 0,1 \mathrm{mg} / \mathrm{kg} \otimes 1 \mathrm{mg} / \mathrm{kg} \quad \square 5 \mathrm{mg} / \mathrm{kg} \quad \square 10 \mathrm{mr} / \mathrm{kr}$

Fig. 2. Catalase activity ( $\mu \mathrm{mol} / \mathrm{min}^{*} \mathrm{~g}$ tis) of rats liver tissue under conditions of subacute effect of various doses of decahedron SNP

Note: $*$ - $\mathrm{p}<0,05$ relative to control

Under conditions of subacute effect of 45 $\mathrm{nm}$ decahedron SNP at 5 and $10 \mathrm{mg} / \mathrm{kg}$ dose there were observed dystrophic changes in the cortical substance of rats kidneys, reversible swelling of the epithelium of the convoluted tubules of the kidneys (90 and $92 \%, \mathrm{p}<0,05$, respectively), hepatocytes (63 and 64\%, p $<0.05)$, intensive removal of the endothelium with denudation of the surface of the blood vessels in the portal tracts and central veins, reversible swelling of the nuclei of cardiomyocytes (16 and 22\%, p <0.05), intensive removal of the endothelium with denudation of the blood surface myocardial vessels, alteration of different caliber bronchus epithelium of ( 96 and $98 \%, p<0.05$ ), blood vessel enlargement in the walls of the respiratory organs of the lungs ( 80 and $84 \%, p<0.05$ ), karyopicnose in neurons of the cortical substance of the rat brain (17 and 18\%, p <0.05), spasm of arterioles with the development of periateriolary edema. The intensity of pathomorphological changes under the decahedron SNP effect increases in a line: lungs, kidneys, liver, heart, brain (tab. 1).

Changes in the prooxidant-antioxidant balance, under conditions of subacute $45 \mathrm{~nm}$ spherical SNP effect, were characterized by a slight increase in prooxidant compounds and moderate activation of antioxidant defense (fig. 3, 4). However, a significant increase in cholesterol was detected $(1.5$ times, $\mathrm{p}<0.05)$.
In addition, the following changes in the internal organs were observed after the introduction of spherical nanosilver in a dose of 5 $\mathrm{mg} / \mathrm{kg}$ : pronounced venous perfusion of the cortical and cerebrospinal fluid and the papilla of the kidney, the reversible swelling of the epithelium of the convoluted tubules with prevalence in the form of hydroperic swelling (72\% $\mathrm{p}<0.05)$, reversible swelling of hepatocytes $(44 \%, p<0.05)$, pronounced venous plethora of central and peripheral hepatic lobes, reversible swelling of nuclei of cardiomyocytes $(28 \%, \mathrm{p}<0.05)$, pronounced venous plethora myocardial infarction, uneven venous plethora of walls of respiratory departments of lungs $(68 \%, p<0.05)$. Moreover, after the introduction of spherical SNP in doses of $0.1,1$ and $5 \mathrm{mg} / \mathrm{kg}$ pathomorphological changes in the brain tissue were not found by the used methods (tab. 2). The intensity of pathomorphological changes under the effect of silver nanospheres increases in a line: heart, liver, lungs, kidneys.

Differences in biochemical and pathomorphological changes in the internal organs of the examined animals indicate a more pronounced toxic effects of the solution of decahedron SNP at the same dose of $5 \mathrm{mg} / \mathrm{kg}$ of body weight. Probably this is due to the fact that solutions of silver with the same mass concentration contain 4 times more decaderos than spheres. In addition, nanodecahedrons have a larger specific 


\section{ОРИГІНАЛЬНІ ДОСЛІДЖЕННЯ}

НАНОТОКСИКОЛОГІЯ

Table 1

Quantitative pathomorphological evaluation of harmful effects of decahedron SNP in rats

\begin{tabular}{|c|c|c|c|c|c|c|}
\hline $\begin{array}{c}\text { Dose of SNP, } \\
\mathbf{m g} / \mathbf{k g}\end{array}$ & Kidney & Liver $^{\mathbf{2}}$ & Heart $^{\mathbf{3}}$ & Lungs $^{\mathbf{4}}$ & Lungs $^{\mathbf{5}}$ & Brain $^{\mathbf{6}}$ \\
\hline 0,1 & -7 & - & - & - & - & - \\
\hline 1 & $54,0 \pm 1,6$ & - & - & - & - & - \\
\hline 5 & $90,0 \pm 1,3$ & $63,0 \pm 2,6$ & $16,0 \pm 1,1$ & $96,0 \pm 0,9$ & $80,0 \pm 3,6$ & $17,0 \pm 1,8$ \\
\hline 10 & $92,0 \pm 0,9$ & $64,0 \pm 2,4$ & $22,0 \pm 1,2$ & $98,0 \pm 0,8$ & $84,0 \pm 3,7$ & $18,0 \pm 1,9$ \\
\hline
\end{tabular}

Notes:

1. Prevalence of recurrent swelling of the epithelium of kidneys' convoluted tubules, $\%$

2. Prevalence of recurrent swelling of hepatocytes, $\%$

3. Prevalence of swelling of nuclei of cardiomyocytes, $\%$

4. Prevalence of alteration of biliary epithelium of different caliber, $\%$

5. Prevalence of hypertrophy of blood vessels in lungs' walls, $\%$

6. Prevalence of karyopic nosis in neurons of cortical substance, $\%$

7. «-» - no changes were found

surface area than a spherical nanoscale. Thus, at the $5 \mathrm{mg} / \mathrm{kg}$ dose of SNP, the total specific surface area of decahedron SNP is almost 9 times greater than that of spherical ones in relation to body weight (tab. 3).

\section{Conclusions}

1. According to the analysis of the geometric characteristics of decahedron silver nanoparticles, it is established that the specific area of decaheders is 2 times bigger than the specific area of the spherical SNP, which provides twice bigger area of the contact of silver nanodecahedron in the biological environment. The decahedron nanoparticle contains 4.3 times less atoms than spherical, and, at the same mass concentration, a solution of nanosilver contains 4 times more silver nano decahedrons than spheres.

2. With the help of biochemical analyses of blood and liver tissue, as well as the morphometric analysis of pathological changes in the

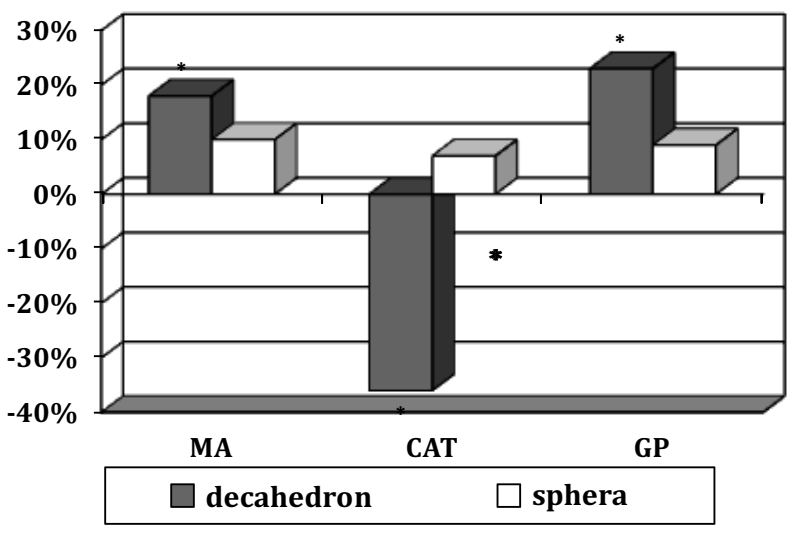

Fig.3. Changes in the parameters of pro- and antioxidant system in rats blood after the introduction of decahedron and spherical SNP at a dose of $5 \mathrm{mg} / \mathrm{kg}$, \%

Note: $*$ - $p<0,05$ relative to control

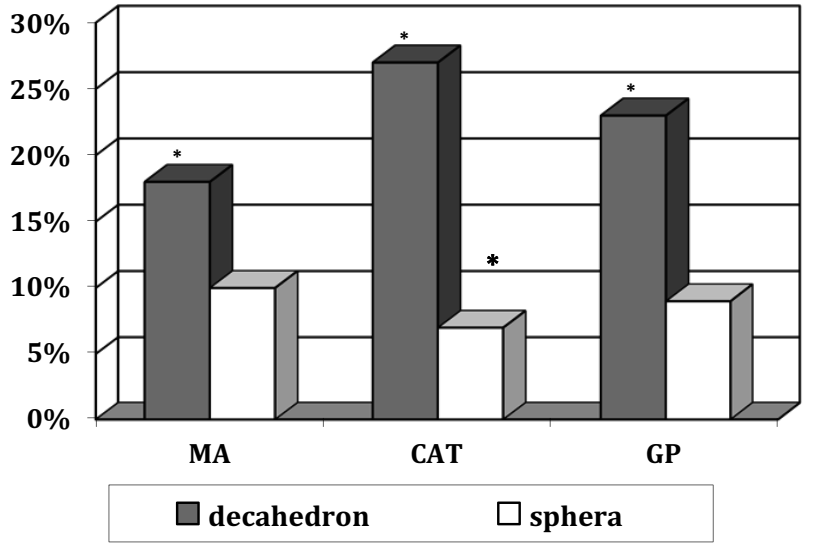

Fig.4. Changes in the parameters of pro- and antioxidant system in rats liver after the introduction of decahedron and spherical SNP at a dose of $5 \mathrm{mg} / \mathrm{kg}, \%$

Note: ${ }^{*}-\mathrm{p}<0,05$ relative to control 


\section{ОРИГІНАЛЬНІ ДОСЛІДЖЕННЯ НАНОТОКСИКОЛОГІЯ}

Quantitative pathomorphological evaluation of harmful effects of silver nanospheras in rats

\begin{tabular}{|c|c|c|c|c|c|c|}
\hline $\begin{array}{c}\text { Dose of SNP, } \\
\mathbf{~ m g / k g}\end{array}$ & Kidney $^{\mathbf{1}}$ & Liver $^{\mathbf{2}}$ & Heart $^{\mathbf{3}}$ & Lungs $^{\mathbf{4}}$ & Lungs $^{\mathbf{5}}$ & Brain \\
\hline 0,1 & -6 & - & - & - & - & - \\
\hline 1 & - & - & - & - & - & - \\
\hline 5 & $72,0 \pm 0,6$ & $44,0 \pm 0,9$ & $55 \pm 0,8$ & $28 \pm 0,7$ & $68,0 \pm 1,7$ & - \\
\hline
\end{tabular}

Notes:

1. Prevalence of recurrent swelling of the epithelium of kidneys' convoluted tubules, $\%$

2. Prevalence of recurrent swelling of hepatocytes, $\%$

3. Prevalence of recurrent swelling of cardiomyocytes, $\%$

4. Prevalence of swelling of nuclei of cardiomyocytes, $\%$

5. Prevalence of hypertrophy of blood vessels in the walls of lungs, $\%$

6. «-» - no changes were found

Table 3

Comparative characteristic of the value of the administered doses of SNP, expressed by various units of measurement

\begin{tabular}{|c|c|c|c|c|}
\hline Dose & \multicolumn{2}{|c|}{ Decahedrons, 45 nm } & \multicolumn{2}{|c|}{ Spheras, 45 nm } \\
\hline \multicolumn{5}{|c|}{ Units } \\
\hline $\mathrm{mg} / \mathrm{kg}$ & part/kg & Sp.area $\mathrm{nm}^{-1} / \mathrm{kg}$ & part/kg & Sp.area $\mathbf{n m}^{-1} / \mathbf{k g}$ \\
\hline 5 & $4,37 * 10^{13}$ & $1,18^{*} 10^{13}$ & $1,02 * 10^{13}$ & $1,32 * 10^{12}$ \\
\hline 1 & $8,74 * 10^{12}$ & $2,36^{*} 10^{12}$ & $2,04 * 10^{12}$ & $2,65^{*} 10^{11}$ \\
\hline 0,1 & $8,74 * 10^{11}$ & $2,36^{*} 10^{11}$ & $2,04 * 10^{11}$ & $2,65 * 10^{10}$ \\
\hline
\end{tabular}

internal organs of laboratory rats, the dosedependent harmful effect of silver nanoparticles of decahedral and, partially, spherical shape was established. The revealed changes in the blood and internal organs of animals testified to a less toxic effect of silver nanospheres in comparison with silver nanodecahedrons.

3. It was established that the differences in biochemical and pathomorphological changes in the internal organs of laboratory animals at the same dose of SNP the decahedron and spherical shape, calculated in $\mathrm{mg} / \mathrm{kg}$ body weight, are related to a 4-multiple dose difference expressed in the ratio of "the number of nanoparticles $/ \mathrm{kg}$ " of body weight and a 9-multiple difference in favor of nanodecahedrons while calculating the dose "specific surface area $/ \mathrm{kg}$ " of body weight.

\section{REFERENCES}

1. Chaloupka K. Nanosilver as a new generation of nanoproduct in biomedical applications / K. Chaloupka, Y. Malam, A. M. Seifalian // Trends in Biotechnology. - 2010. - V.28 (11). - P. 580-588.

2. Histological study of gender differences in accumulation of silver nanoparticles in kidneys of Fischer 344 rats / W.Y. Kim, J. Kim, J. D. Park [et al.] //Journal of Toxicology and Environmental Health, Part A. - 2009. - V. 72, № 21-22. - P. 1279-1284.
3. Ion-release kinetics and ecotoxicity effects of silver nanoparticles / Yong-Julee, J. Kim, J. Oh // Environmental Toxicology and Chemistry. - 2012. - V.31 (1). - P.155-159.

4. In vivo induced nephrotoxicity of silver nanoparticles in rat after oral administration / M. H. Gherkhbolagh, Z. Alizadeh, M. Asari [et al.] // Journal of Research in Medical and Dental Science- 2018. - V. 6, № 6. - P. 43-51.

5. Metal-based nanoparticles and their toxicity assessment / A.M. Schrand, M.F. Rahman, S.M. Hussain [et al.] // Wires 


\section{ОРИГІНАЛЬНІ ДОСЛІДЖЕННЯ НАНОТОКСИКОЛОГІЯ}

Nanomedicine and Nanobiotechnology. - 2010. - V. 2, № 5. - P. 544-568.

6. Murshid N. Optimized Synthetic Protocols for Preparation of Versatile Plasmonic Platform Based on Silver Nano-particles with Pentagonal Symmetries / N. Murshid, D. Keogh, V. Kitaev //Particle \& Particle Systems Characterization. 2014. - V. 31, № 2. - P. 178-189.

7. Nanosilver / R. Fries, S. Greßler, M. Simkó [et al.] // Nano Trust Dossiers. - 2010. - V. 10. - P. 1-7.

8. Repeated-dose toxicity and inflammatory responses in mice by oral administration of silver nanoparticles / E.J. Park, E. Bae, J.Yi [et al.] // Environmental toxicology and pharmacology. - 2010. - V. 30, № 2. - C. 162-168.

9. Subchronic inhalation toxicity of silver nanoparticles / J.H. Jung, J.H. Ji, J.D. Park [et al.] // Toxicological Science. - 2009. - V. 108 (2). - P. 452-461.

10. Subchronic oral toxicity of silver nanoparticles / Y.S. Kim, M.Y. Song, J.D. Park [et al.] // Particle and Fibre Toxicology. - 2010. - V. 7 (20). - P. 1-12.

11. The effect of particle size on the cytotoxicity, inflammation, developmental toxicity and genotoxicity of silver nanoparticles / M.V.D.Z. Parka, A.M. Neighc, J.P. Vermeulen [et al.] // Biomaterials. - 2011. - Vol. 32 (7). - P. 9810-9817.

12. The kinetics of the tissue distribution of silver nanoparticles of different sizes / D.P.K. Lankveld, A.G. Oomen, P. Krystek [et al.] // Biomaterials. - 2010. - № 31. P. 8350-8361.

13. The possible mechanism of silver nanoparticle impact on hippocampal synaptic plasticity and spatial cognition in rats / Y. Liua, W. Guana, G. Ren [et al.] // Toxicology Letters. - 2012. - V. 209 (34). - P. 227- 231.

14. Time-dependent biodistribution and excretion of silver nanoparticles in male Wistar rats / K. Dziendzikowska, J. Gromadzka-Ostrowska, A. Lankoff [et al.] // J. Appl. Toxicol. - 2012. - V. 32, № 11. - P. 920-928.

15. Twenty-Eight-Day Inhalation Toxicity Study of Silver Nanoparticles in Sprague-Dawley Rats / Jun Ho Ji, Jae Hee Jung, Sang Soo Kim [et al.] // Inhalation Toxicology. 2007. - № 19. - P. 857-871.

16. Twenty-Eight-Day Oral Toxicity, Genotoxicity, and Gender-Related Tissue Distribution of Silver Nanoparticles in Sprague-Dawley Rats / Y.S. Kim, J.S. Kim, H.S. Cho [et al.] // InhalationToxicology. - 2008. - V. 20 (11). - P. 575583.

\section{ДОСЛІДЖЕННЯ ТОКСИЧНОСТІ НАНОЧАСТИНОК СРІБЛА ДЕКАЕДРИЧНОЇ ТА СФЕРИЧНОЇ ФОРМИ В ПІДГОСТРОМУ ЕКСПЕРИМЕНТІ НА ЩУРАХ}

Н.Й. Андрійчук' ${ }^{1}$ Л.І. Власик,

${ }^{1}$ Вищий державний навчальний заклад Украӥни

“Буковинський державний медичний університет”, м. Чернівиі, Україна

${ }^{2}$ ДП "Науковий центр превентивної токсикології, харчової та хімічної безпеки імені академіка Л.І. Медведя МОЗ України, м. Чернівиі, Україна

PEЗЮМЕ. Безпека наноматеріалів і нанотехнологій - важливий фактор у регулюванні промислового виробництва і впровадженні нанопродуктів у практику. Токсикологічний аспект використання наночастинок срібла недостатньо вивчений, тому багато питань залишаються без відповідей. Проблема залежності токсичності від форми і розміру наночастинок $\epsilon$ спірною, крім того, існує брак досліджень стосовно впливу наносрібла на організм людини і тварин.

Метою дослідження було провести гігієнічну оцінку шкідливого впливу наночастинок срібла сферичної та декаедричноі форми.

Матеріали та методи. Зразки розчинів наносрібла сферичної та декаедричної форм, синтезовані методом фотостимульованого синтезу, вводили внутрішньоочеревинно білим нелінійним шурам обох статей віком 4 місяці. Для дослідження підгострої токсичності срібних наносфер, діаметром 45-нм, тварини були розділені на три групи (по 16 щурів у кожній, по 8 тварин у підгрупі - в залежності від статі). Щодня їм вводили розчин наносрібла в дозах 0,1, 1 і 5 мг/кг внутрішньоочеревинно протягом 14 днів. Четвертою групою був біологічний контроль. Для дослідження підгострої токсичності наносрібла декаедричної форми, 45 нм, щури були розділені на чотири групи (16 шурів у кожній, 8 тварин у підгрупі в залежності від статі). Тваринам вводили внутрішньоочеревинно дози наночасток 10, 5, 1 і 0,1 м / кг щодня протягом 14 днів. П'ята група була біологічним контролем. На 14-й день тварини були виведені з експерименту шляхом декапітації під легким ефірним наркозом.

Результати та обговорення. Розраховано і обгрунтовано доцільність врахування фізико-хімічних властивостей наночастинок срібла, в тому числі геометричних характеристик (форма, питома площа поверхні), кількості іонів срібла в наночастинках і кількості наночастинок в розчині при визначенні експозиції наносрібла або інших нанохімікатов різної геометричної форми.

На моделях підгострого впливу визначено особливості впливу наносрібла різної форми і гігієнічне значення біохімічних $i$ патоморфологічних змін, як критеріїв шкідливого впливу. За допомогою морфометричного аналізу патоморфологічних змін внутрішніх органів шурів встановлено дозозалежний шкідливий вплив наночастинок срібла декаедричної та сферичної форм. В результаті експерименту спостерігалося дозозалежне зворотне набухання епітелію звивистих канальців нирок, гепатоцитів, ядер кардіоміоцитів, альтерація епітелію бронхів різного калібру, повнокрів'я кровоносних судин стінок респіраторних відділів легень, каріопікноз нейронів коркової речовини мозку. Виявлені зміни показників прооксидантно-антиоксидантної рівноваги деяких біохімічних показників і внутрішніх органів тварин свідчили про менш токсичний вплив срібних наносфер порівняно з нанодекаедрами срібла.

Висновки. 1. За результатами аналізу геометричних характеристик декаедричних наночастинок срібла встановлено, що питома площа декаедрів удвічі більша за питому площу сферичних наночастинок, що забезпечує вдвічі більшу площу контакту нанодекаедра срібла в біологічному середовищі. Наночастинка декаедра містить в 4,3 разу менше атомів, ніж сферична, а за такої ж масової концентрації розчин наносрібла містить у 4 рази більше нанодекаедрів срібла, ніж сфер.

2. За допомогою біохімічних досліджень крові та тканини печінки, а також морфометричного аналізу патоморфологічних змін внутрішніх органів лабораторних шурів встановлено дозозалежну шкідливу дію наночастинок срібла декаедричної $i$ 


\section{ОРИГІНАЛЬНІ ДОСЛІДЖЕННЯ НАНОТОКСИКОЛОГІя}

частково сферичної форми. Виявлені зміни в крові і внутрішніх органах тварин свідчили про менш токсичний вплив срібних наносфер порівняно з нанодекаедрами срібла.

3. Встановлено, що відмінності біохімічних і патоморфологічних змін у внутрішніх органах лабораторних тварин за однакової дози наночастинок срібла декаедричної і сферичної форми, розраховані в мг/кг маси тіла, пов'язані з 4-кратною різницею в дозі, вираженої у співвідношенні «кількість наночастинок/кә» маси тіла і 9-кратної різниці на користь нанодекаедрів при розрахунку дози «питома площа поверхні/ке» маси тіла.

Ключові слова: наночастинки срібла, срібний нанодекаедр, срібна наносфера, токсичність, наносрібло.

\section{ИССЛЕДОВАНИЕ ТОКСИЧНОСТИ НАНОЧАСТИЦ СЕРЕБРА \\ В ПОДОСТРОМ ЭКСПЕРИМЕНТЕ НА КРЫСАХ}

Н.И. Андрийчук ${ }^{1}$, Л.И. Власык $\kappa^{1,2}$

${ }^{1}$ Высшее государственное учебное заведение Украины

“Буковинский государственный медицинский университет”, г. Черновцы, Украина

${ }^{2}$ ГП «Научный центр превентивной токсикологии, пищевой

и химической безопасности имени академика Л.И.Медведя МЗ Украины», г. Черновцы, Украина

PЕЗЮМЕ. Безопасность наноматериалов и нанотехнологий - важный фактор в регулировании промышленного производства и внедрения нанопродуктов в практику. Токсикологический аспект использования наночастии серебра недостаточно изучен, поэтому многие вопросы остаются без ответа. Проблема зависимости токсичности от формы и размера наночастии спорна и недостаточно хорошо изучена, кроме этого, недостаточно исследовано воздействие наносеребра на организм человека и животных.

Целью работы было провести гигиеническую оценку вредного воздействия наночастиц серебра сферической и декаэдрической формы.

Материалы и методы. Образиы растворов наносеребра сферической и декаэдрической форм, синтезированных методом фотостимулированного синтеза, вводили внутрибрюшинно белым нелинейным крысам как самиам, так и самкам в возрасте 4 месяцев. Для исследования подострой токсичности серебряных наносфер, диаметр 45-нм, животные были разделены на три группы (по 16 крыс в каждой, по 8 животных в подгруппе - в зависимости от пола). Каждый день им вводили раствор наносеребра в дозах 0,1, 1 и 5 мг/кг внутрибрюшинно в течении 14 дней. Четвертой группой был биологический контроль. Для исследования подострой токсичности наносеребра декаэдрической формы, 45 нм, крысы были разделены на четыре группы (16 крыс в каждой, 8 животных в подгруппе - в зависимости от пола). Животным вводили внутрибрюшинно дозы наночастии 10, 5, 1 и 0,1 м/кг ежедневно в течении 14 дней. Пятая группа была биологическим контролем. На 14-й день животные были выведены из эксперимента путем обезглавливания под легким эфирным наркозом.

Результаты и обсуждение. Рассчитана и обоснована иелесообразность учета физико-химических свойств наночастии, серебра, в том числе геометрических характеристик (форма, удельная площадь поверхности), количества ионов серебра в наночастицах и количества наночастии в растворе при определении экспозиции наносеребра или других нанохимикатов различной геометрической формы.

На моделях подострого воздействия определены особенности влияния наносеребра различной формы и гигиеническое значение биохимических и патоморфологических изменений, как критериев вредного воздействия. С помощью морфометрического анализа патоморфологических изменений внутренних органов крыс установлено дозозависимое вредное действие наночастии серебра декаэдрической и сферической форм. В результате эксперимента отмечено дозозависимое оборотное набухание эпителия извитых канальцев почек, гепатоцитов, ядер кардиомиоцитов, альтерацию эпителия бронхов разного калибра, полнокровие кровеносных сосудов стенок респираторных отделов легких, кариопикноз нейронов коркового вещества мозга. Выявленные изменения показателей прооксидантно-антиоксидантного равновесия, некоторых биохимических показателей и внутренних органов животных свидетельствовали о менее токсическом воздействии серебрянных наносфер в сравнении с нанодекаэдрами серебра.

Выводы. 1. По результатам анализа геометрических характеристик декаэдрических наночастии серебра установлено, что удельная площадь декаедров в 2 раза больше удельной площади сферических наночастиц, что обеспечивает вдвое большую площадь контакта нанодекаэдра серебра в биологической среде. Наночастииа декаэдра содержит в 4,3 раза меньще атомов, чем сферическая, а при той же массовой концентрации раствор наносеребра содержит в 4 раза больше нанодекаэдров серебра, чем сфер.

2. С помощью биохимических исследований крови и ткани печени, а также морфометрического анализа патоморфологических изменений внутренних органов лабораторних крыс установлено дозозависимое вредное действие наночастии серебра декаэдрической и частично сферической форм. Выявленные изменения в крови и внутренних органах животных свидетельствовали о менее токсическом воздействии серебряных наносфер в сравнении с нанодекаэдрами серебра.

3. Установлено, что различия в биохимических и патоморфологических изменениях во внутренних органах лабораторных животных при одинаковой дозе наночастии серебра декаэдрической и сферической форм, рассчитанные в мг/кг массы тела, связаны с 4-кратной разницей в дозе, выраженной в соотношении «количество наночастии/кг» массы тела и 9кратной разницы в пользу нанодекаэдров при расчете дозы «удельная площадь поверхности/кг» массы тела.

Ключевые слова: наночастицы серебра, серебряный нанодекаэдр, серебряная наносфера, токсичность, наносеребро.

Надійшла до редакції 22.04.2019 р. 